\title{
PENERAPAN METODE GRAND MBA PADA PEMBELAJARAN ALQURAN DALAM MENINGKATKAN KEMAMPUAN MEMBACA ALQURAN SISWA DI MTS HIDAYATULLAH DENPASAR TAHUN PELAJARAN 2019/2020
}

\author{
Syamsul Arifin, ${ }^{1}$ Achmad Qosim, ${ }^{2}$ Khoeron. ${ }^{3}$ \\ ${ }^{1,3}$ Program Studi Pendidikan Agama Islam, Sekolah Tinggi Agama Islam Denpasar Bali, \\ Denpasar, Indonesia \\ ${ }^{2}$ Program Studi Pendidikan Agama Islam, Sekolah Tinggi Agama Islam Denpasar Bali, \\ Denpasar, Indonesia
}

e-mail: \{pamansam084@gmail.com, staidenpasar@gmail.com,khoeron71@yahoo.com\}

\begin{abstract}
ABSTRAK
Penelitian ini dilatar belakangi oleh salah satu fenomena siswa khususnya siswa MTs. Banyak dari mereka masih belum bisa membaca Alquran, maka dari itu guru memiliki peranan untuk meningkatkan kemampuan membaca Alquran siswa. Tujuannya untuk mendiskripsikan penerapan metode Grand MBA pada pembelajaran Alquran dalam meningkatkan kemampuan membaca Alquran siswa di MTs Hidayatullah Denpasar, mendiskripsikan kualitas kemampuan baca Alquran siswa di MTs Hidayatullah Denpasar, mendiskripsikan faktor pendukung dan penghambat penerapan metode Grand MBA di MTs Hidayatullah Denpasar. Jenis penelitian ini adalah deskriptif dengan pendekatan kualitatif dengan tiga teknik pengumpulan data yaitu: observasi, dokumentasi, dan wawancara. Hasil penelitian ini menunjukkan bahwa: penerapan metode Grand MBA dalam meningkatkan kemampuan membaca Alquran siswa di MTs Hidayatullah dilakukan secara klasikal dan dapat dikategorikan baik, kualitas siswa dibuktikan dengan meningkatnya kemampuan siswa dalam membaca Alquran dengan baik dan benar. Sedangkan faktor pendukung diantaranya: kualitas guru yang baik sedangkan faktor penghambatnya adalah kurangnya kesadaran siswa dalam mengikuti pengajaran Alquran. Hasil penelitian ini diharapkan dapat dijadikan tambahan pengetahuan dan masukan bagi pengelola lembaga pendidikan yang beorientasi terhadap pembelajaran Alquran.
\end{abstract}

Kata kunci: Metode Grand MBA, Pembelajaran Alquran

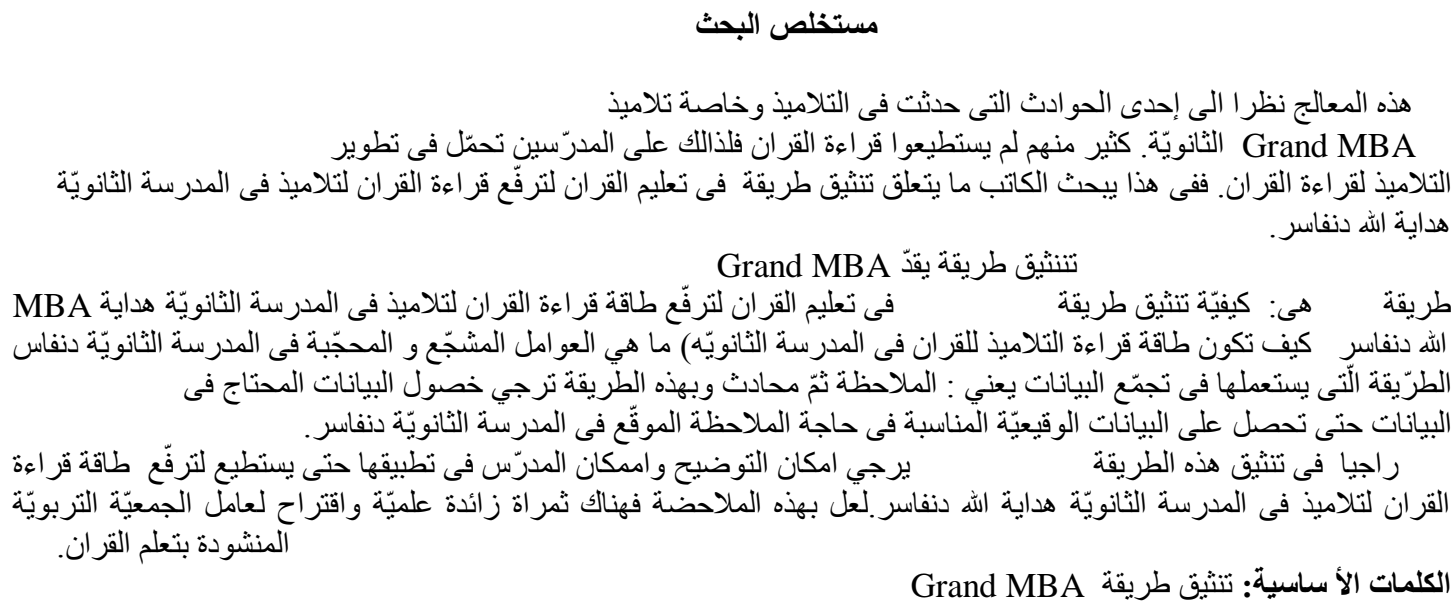

Grand MBA الكلمات الأ ساسية: تتنيق طريقة

\section{PENDAHULUAN}

Alquran adalah firman Allah sekaligus mukjizat yang paling agung yang diturunkan kepada Nabi Muhammad SAW melalui malaikat Jibril. Dengan mambaca dan menghayati arti Alquran disamping menuai pahala ibadah (al-mutaabbad biitilawatihi), dapat juga membangkitkan perasaan manusia 
agar dapat merasakan keindahan yang terhampar di alam semesta ini, yang diciptakan Allah SWT dengan membaguskan serta mendesain secara detail sesuatu yang ada. Orisininalitas keberadaan Alquran, baik dari esensi bacaannya ataupun kebenaran cara membacanya mulai dari awal kali diturunkan hingga sampai kapanpun pasti akan tetap tejaga. Allah SWT menjamin sendiri orisinalitas keberadaan Alquran. Pendistorsian (Tahrif) terhadap Alquran, baik dari segi isi ataupun bacaan pasti akan ditampakkan Allah melalui penghafal Alquran dan orang-orang yang senantiasa concern (istiqomah) mempelajari Alquran Allah SWT berfirman:

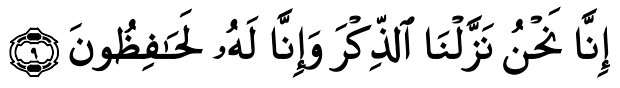

\begin{tabular}{llrr}
\multicolumn{2}{c}{ "Sesungguhnya } & Kamilah yang \\
menurunkan Az-Dzikr & (Alquran) dan \\
sesungguhnya & Kamilah yang benar-benar \\
akan menjaganya". (QS. Al-Hijr: 9) & 1
\end{tabular}

Menurut Imam Al Ghazali, hal-hal yang dapat menjaga keberadaan Alquran hingga akhir zaman adalah mereka yang senantiasa menghafal Alquran dalam hatinya, terus menerus mempelajari Alquran berikut dengan tata cara dan etika membaca dan mendalami Alquran. Karena keagungan dan kemuliaan Alquran, maka orang yang belajar dan mengajakan Alquran termasuk orang-orang yang mulia. Nabi Muhammad bersabda dalam salah satu haditsnya:

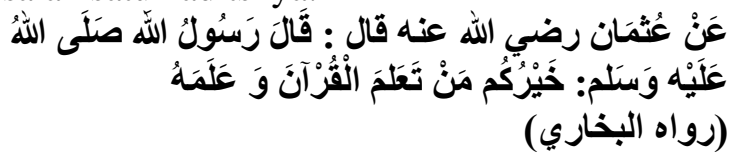

Dari Utsman bin Affan RA, Rasulullah bersabda: "Sebaik-baiknya kamu adalah orang yang belajar Alquran dan mengajarkannya." (HR. Bukhari) $^{2}$

Oleh karena itu, sebagai orang tua sudah seharusnya turut mempehatikan dan betanggung jawab terhadap perkembangan agama anak-anak. Karena perkembangan agama anak sangat ditentukan oleh pendidikan

${ }^{1}$ Al-Quran dan Terjemah Kemenag RI 1993, Surat Al-Hijr/15 Ayat 9 h. 244

${ }^{2} \mathrm{Abu}$ Zakariya an-Nawawi, Riyadhu AlSholihin, (Bairut Libanon: Dar Tuqun Najah, 2002), h. 495 dan pengalaman yang dilaluinya, terutama pada masa pertumbuhan yang pertama (masa anak berumu 0-12 tahun).

Dewasa ini banyak diantara anak-anak usia remaja khususnya anak MTs/SMP yang mana mereka tidak bisa membaca Alquran.

Tajul Arifin mengungkapkan, berdasarkan data secara nasional yang dihimpun UIN Sunan Gunung Djati, pada tahun 2015, sedikitnya 54\% Muslim Indonesia terkategori buta huruf Alquran "Jadi, baru 46\% Muslim yang melek Alquran dan mampu membaca Alquran. Kalau dimasukkan indikator bisa memahami isi Alquran, tentu jauh lebih kecil lagi," katanya. Ia mengatakan, 46\% Muslim itu terkategori bisa membaca Alquran beserta ilmu tajwid. "Bisa jadi, ketika TK sampai SD sudah bisa membaca Alquran karena memang diajarkan. Namun, memasuki SMP sampai dewasa tidak dipakai lagi sehingga lupa terhadap huruf Alquran," tuturnya. ${ }^{3}$

Dan begitu juga di MTs Hidayatullah Denpasar dari data tahun-tahun sebelumnya juga terjadi hal demikian banyak diantara mereka para siswa tahun-tahun sebelum nya hampir $50 \%$ dari mereka yang belum bisa membaca Alquran khususnya mereka yang lulusan SD yang mana jam pelajaran untuk belajar Alquran sangat terbatas sekali.

Untuk mengantisipasi hal tersebut, di MTs Hidayatullah sebagai lembaga pendidikan Islam hendaknya dapat mengkoreksi diri dan melakukan langkah-langkah positif untuk mengembangkan pengajaran Alquran, sebagai salah satu media untuk belajar dan memperdalam isi kandungan Alquran itu perlu ditingkatkan dengan menggunakan metode dan tehnik baca tulis Alquran praktis, efektif dan efisien, serta dapat mengantarkan siswa cepat dan tanggap untuk menguasai Belajar dan Membaca Alquran pada saat sekarang ini.

Untuk dapat membaca Alquran dengan tartil dan sesuai kaidah-kaidah yang berlaku diperluakan suatu bidang disiplin ilmu yang lazim disebut ilmu tajwid. Ilmu yang dapat mengantarkan para pembaca Alquran mampu membaca dengan benar, teratur, indah dan

\footnotetext{
${ }^{33}$ https://pikiran-rakyat.com/nasional/pr01290792/ironis-54\%-muslimindonesiatakbisaalquran
} 
fasih sehingga terhindar dari kekeliruan dan kesalahan dalam membacanya.

Dalam mengajarkan Alquran seorang guru atau ustadz/ustadzah dapat menggunakan metode yang bermacam-macam. Yang mana setiap metode tersebut memiliki keistimewaan masing-masing. Karena keberagaman ini guru bisa memilih metode mana yang dirasakan cocok dan efisien untuk digunakan dalam pembelajaran. Metode-metode tersebut seperti metode Baghdadiyah, Qiroa'ti, Tilawati, al Barqy, Iqra dll. Salah satu metode yang digunakan di Indonesia adalah metode Grand MBA, yang akan Penulis kaji tentunya dari metode ini tujuannya satu yaitu menjaga kebenaraan dan kecepatan untuk bisa membaca Alquran dengan baik (berseni) dan benar (bertajwid).

Metode pembelajaran Grand MBA ini pertama kali disusun oleh Ust. Karim Bonggo (Alm) dkk di Pesantren Hidayatullah pusat Balikpapan. Buku metode Grand MBA ini disusun/dicetak dalam empat paket yaitu: 1 . Paket baca 6 jilid, 2. Paket tahsin dan tajwid, 3. Paket tarjamah, dan 4. Materi ta'lim diniyah. Dimana dalam setiap paketnya terdapat petunjuk mengajar dengan tujuan untuk memudahkan setiap peserta didik (siswa/santri) yang akan menggunakannya, maupun Guru (ustadz/ustadzah) yang akan menerapkan metode tersebut kepada siswa atau santrinya. Metode Grand MBA ini termasuk metode baru dan telah banyak memberikan kemudahan sejak diluncurkan tahun 2005 hingga kini terus dikembangkan untuk mewujudkan kemudahan dalam belajar Alquran. ${ }^{4}$

Di MTs Hidayatullah menurut data tahun-tahun sebelumnya hampir 50\% mereka tidak bisa membaca Alquran, khususnya mereka yang lulusan SD. Maka dengan metode Grand MBA ini diharapkan dapat memudahkan siswa untuk belajar Alquran. Metode ini sangat cocok diterapkan karena pengajarannya secara klasikal dan juga atas perintah/arahan dari yayasan yang menaunginya.

Dari uraian di atas, Penulis merasa tertarik untuk meneliti "Penerapan metode Grand MBA Pada Pembelajaran Alquran

\footnotetext{
${ }^{4}$ Agung Trana jaya, Buku Terampil Menejemah al-Quran Dan membaca kitab Gundul, (Majelis Al-Quran Hidayatullah, www.posdai.or.id)
}

Dalam Meningkatkan Kemampuan Membaca Alquran Siswa di MTs Hidayatullah Denpasar". MTs Hidayatullah adalah salah satu lembaga pendidikan Islam yang memprioritaskan pembelajaran dalam bidang Alquran. MTs Hidayatullah menggunakan strategi pembelajaran Alquran dalam proses belajar mengajar dengan metode Grand MBA untuk meningkatkan kemampuan baca Alquran siswanya. Maka dari itu Penulis tertarik untuk menjadikan MTs Hidayatullah sebagai objek dalam penulisan.

Pengertian penerapan adalah "perbuatan menerapkan, sedangkan menurut beberapa ahli berpendapat bahwa, penerapan adalah suatu perbuatan mempraktekkan suatu teori, metode, dan hal lain untuk mencapai tujuan tertentu dan untuk suatu kepentingan yang diinginkan oleh suatu kelompok atau golongan yang telah terencana dan tersusun sebelumnya".

Metode. Istilah metode berasal dari bahasa Yunani yaitu Methodos yang berasal dari kata "meta" dan "hodos". Kata meta berarti melalui sedang hodos berarti jalan, sehingga metode berarti jalan yang harus dilalui, cara melakukan sesuatu atau prosedur. Adapun dalam bahasa Arab bisa bermakna "Minhaj, al wasilah, Al Raifiyah, AlThoriqoh". Semua kata ini berarti jalan atau cara yang harus ditempuh.

Buku Grand MBA diprakarsai oleh Ust. Karim Bonggo (Alm) dan mulai diluncurkan pada tahun 2005 ke sekolah-sekolah dan pesantren serta jamaah Hidayatullah di seluruh nusantara. Grand MBA sendiri merupakan singkatan dari Gerakan Dakwah Mengajar dan Belajar Alquran, hingga dikenal sampai saat ini dengan Metode Grand MBA.

Pembelajaran terkait membelajarkan siswa bagaimana membuat siswa dapat belajar dengan mudah dan terdorong oleh kemauanya sendiri untuk mempelajari apa yang teraktualisasikan dalam kurikulum Madrasah sebagai kebutuhan siswa. Oleh karena itu pembelajaran berupaya menjabarkan nilai-nilai yang terkandung dalam kurikulum dengan menganalisis tujuan pembelajaran dan karakteristik isi bidang studi pendidikan agama yang terkandung di dalam kurikulum.

Dalam pembelajaran terdapat tiga komponen atau faktor utama yang saling mempengaruhi dalam poses pembelajaran

\footnotetext{
${ }^{5}$ https:/www.kanalinfo.web.id/menerapkan
} 
pendidikan agama. Ketiga komponen itu adalah: (1) kondisi pembelajaran Alquran; (2) metode pembelajaran Alquran; (3) hasil pembelajaran Alquran. ${ }^{6}$

Fokus permasalahan dalam penelitian ini adalah: "(1) Bagaimana penerapan metode Grand MBA pada pembelajaran Alquran dalam meningkatkan kemampuan membaca Alquran siswa di MTs Hidayatullah Denpasar Tahun Pelajaran 2019-2020? (2) Bagaimana cara meningkatkan kemampuan membaca Alquran siswa di MTs Hidayatullah Denpasar? (3) Faktor apa saja yang menjadi pendukung dan penghambat dalam penerapan metode Grand MBA di MTs Hidayatullah Denpasar tahun pelajaran 2019/2020?

Untuk mendapatkan jawaban dari fokus permasalahan dalam penelitian tersebut, maka peneliti melakukan kajian melalui metode deskriptif kualitatif sebagaimana paparan pada bagian metode penelitian dalam artikel ini.

Tujuan dari penelitian ini adalah untuk mengetahui: (1) Untuk mendiskripsikan penerapan metode Grand MBA pada pembelajaran Alquran dalam meningkatkan kemampuan membaca Alquran siswa di MTs Hidayatullah Denpasar tahun ajaran 20192020. (2) Untuk mendiskripsikan kualitas kemampuan baca Alquran siswa di MTs Hidayatullah Denpasar. (3) Untuk mendiskripsikan Faktor pendukung dan penghambat penerapan metode Grand MBA di MTs Hidayatullah Denpasar.

\section{METODE PENELITIAN}

Sesuai dengan judul yang dikemukakan yakni: "penerapan metode Grand MBA pada pembelajaran Alquran dalam meningkatkan kemampuan membaca Alquran siswa di MTs Hidayatullah Denpasar tahun ajaran 20192020". Maka pendekatan dalam penelitian ini adalah penelitian kualitatif dengan berusaha melaksanakan pengkajian data deskriptif yang akan dituangkan dalam bentuk laporan atau uraian. Penelitian ini merupakan studi deskriptif analitis maka dalam memperoleh data yang sebanyak-banyaknya dilakukan melalui berbagai teknik yang disusun secara

${ }^{6}$ Muhaimin, dkk. Paradigma Pendidikan Islam. Suatu Upaya Mengefektifkan Pendidikan Agama di Sekolah, (Bandung: Rosda Karya, 2002), h. 146 sitematis untuk mencari pengumpulan data hasil penelitian yang sempurna. Penulis melakukan penelitian dengan studi deskriptif karena sesuai dengan sifat masalah serta tujuan penelitian yang ingin diperoleh.

Dalam penelitian kali ini, teknik pengumpulan data yang digunakan adalah Pertama, Interview (Wawancara):

Menurut Asep Saiful Muhtadi dan Agus Ahmad Safei:

"Metode interview (wawancara) adalah salah satu metode pengumpulan data yang dilakukan langsung berhadapan dengan narasumber maupun tidak atau dengan cara memberikan daftar pertanyaan untuk dijawab. Kelebihan dari metode ini adalah: Peneliti bisa mendapatkan keterangan dengan lebih mudah, cepat, detil, jelas dan pasti dari narasumber". 7

Pedoman wawancara yang digunakan peneliti adalah wawancara bebas atau tak berstruktur, yaitu wawancara yang tidak di dasarkan atas suatu sistem dan daftar pertanyaan yang telah disediakan sebelumnya, tapi pedoman wawancara digunakan hanya berisi garis-garis besar masalah yang akan digunakan. ${ }^{8}$

Kedua. Observasi: "Observasi atau pengamatan adalah alat pengumpulan data yang dilakukan dengan cara mengamati dan mencatat secara sistematik fenomenafenomena yang diteliti dengan cara mengadakan pengamatan langsung terhadap objek kemudian hasil pengamatan tersebut dituangkan dalam sebuah catatan". 'Dalam penelitian ini peneliti telah melakukan observasi atau pengamatan terhadap ruang (tempat), pelaku, kegiatan, objek, perbuatan, kejadian atau peristiwa, waktu dan perasaan terkait dengan penerapan metode Grand MBA pada pembelajaran Alquran dalam meningkatkan kemampuan membaca Alquran

${ }^{7}$ Asep Saiful Muhtadi, Metodologi Penelitian Dakwah, (Bandung: CV. Pustaka Mulia, 2003), h. 167

${ }^{8}$ Deddy Mulyana, Ilmu Komunikasi Suatu Pengantar (Bandung: PT. Remaja Rosdakarya, 2005), h. 245

${ }^{9}$ Suharsimi Arikunto, Prosedur Penelitian: Suatu Pendekatan Praktik, Edisi Revisi VI, (Jakarta: PT. Rineka Cipta, 2006) h. 146 
siswa di MTs Hidayatullah Denpasar tahun ajaran 2019-2020.

Ketiga, Dokumentasi "Metode dokumentasi adalah salah satu metode pengumpulan data kualitatif dengan melihat atau menganalisis dokumen-dokumen yang dibuat oleh subjek sendiri. Dokumentasi merupakan salah satu cara yang dapat dilakukan peneliti kualitatif untuk mendapatkan gambaran dari sudut pandang subjek melalui suatu media tertulis dan dokumen lainnya yang ditulis atau dibuat langsung oleh subjek yang bersangkutan". ${ }^{10}$

Dokumentasi dalam penulisan ini digunakan untuk mencari dan mengumpulkan data-data pendukung yang dibutuhkan dalam penulisan ini. Data-data tersebut adalah data yang berkaitan dengan penerapan metode Grand MBA dalam pembelajaran membaca Alquran, misalnya dalam menyampaikan materi, penilaian mengaji Grand MBA, data profil sekolah, guru dan siswa MTs Hidayatullah Denpasar, serta data pendukung lainnya.

Untuk membuktikan bahwa apa yang diamati peneliti sesuai dengan apa yang sesungguhnya dan yang sebenarnya terjadi pada objek penelitian maka dibutuhkanlah keabsahan data. Dalam penelitian ini, peneliti menggunakan uji kredibilitas yang dilakukan dengan triangulasi. Teknik analisis data dalam penelitian ini dilakukan secara bersamaan dengan proses pengumpulan data dengan tahapan reduksi data, penyajian data, pengambilan kesimpulan. Informan dalam penelitian ini yakni Kepala sekolah, Waka Kesiswaan, Guru Quran, Murid kelas 7, 8, 9 dan masyarakat.

\section{HASIL DAN PEMBAHASAN}

Hasil yang didapatkan berdasarkan data yang diperoleh melalui tekhnik observasi, dokumentasi dan wawancara di Mts Hidayatullah Denpasar, dapat dipaparkan sebagai berikut.

\section{PENERAPAN METODE GRAND MBA}

Mengenai penerapan metode Grand MBA, di MTs Hidayatullah ini memang sangat mengedepankan teori dan praktek dalam

\footnotetext{
${ }^{10}$ Haris Herdiansyah, Metode Penelitian Kualitatif untuk Ilmu-ilmu Sosial, (Jakarta: Salemba Humanika, 2010) h. 143
}

meningkatkan kemampuan baca Alquran siswa. Dimana para guru ikut terlibat dalam proses pembelajaran Metode Grand MBA. Bapak Lukman Hakim selaku Kepala Madrasah berpendapat mengenai perihal ini, seperti yang diperoleh melalui wawancara berikut:

"Metode Grand MBA adalah sebuah cara mengajar belajar Alquran yang efektif dan praktis bukan hanya menterjemahkan Alquran tapi siswa diajarkan dari pengenalan huruf (pra tahsin) sampai bisa menterjemahkan Alquran secara mandiri”." ${ }^{11}$

Selanjutnya Bapak Burhani selaku Waka Kesiswaan sekaligus guru Quran, beliau berpendapat:

"Bahwa penerapan metode Grand MBA adalah tata cara mempelajari serta menterjemah Alquran secara lafdziyah sebuah terobosan untuk mempermudah siswa memahami Alquran". ${ }^{12}$

Intinya dalam teori pembelajarannya sangat penting diketahui oleh siswa konsep pengajaran dalam penerapan Metode Grand MBA untuk mencapai target yang sesuai direncanakan sekolah, adapun dalam hal ini telah disampaikan oleh bapak Bahriawan diantaranya beliau mengatakan:

"Dalam pengajaran metode Grand MBA ada 11 tehnik pengajaran metode Grand MBA: (1) Guru membaca ayat diikuti oleh siswa, (2) Guru membaca perkata sampai selesai satu ayat siswa menyimak, (3) Guru mulai menterjemahkan perkata, siswa menyimak, (4) Guru membaca dan menerjemahkan perkata, diikuti siswa secara klasikal, (5) Guru menyebut kata perkata, siswa menerjemahkan, (6) Guru menyebutkan kata secara acak, siswa menerjemahkan, (7) Asistensi/mentoring (peserta berpasangan dua-dua atau berkelompok seorang membaca perkata dan pasangannya menerjemahkan), (8) Evaluasi (ayat diterjemahkan kata

\footnotetext{
${ }^{11}$ LukmanHakim, Kepala Madrasah, Wawancaa Pribadi di Denpasar pada hari Sabtu 15 Agustus 2020 pukul 10.00 WITA

${ }^{12}$ Burhani, waka kesiswaan, Wawancara Pribadi di Denpasar pada hari Kamis 20 Agustus 2020 pukul 11.50 WITA
} 
perkata oleh seorang siswa yang ditunjuk atau yang bersedia), (9) Guru menyampikan materi penjelasan, (10) Guru menyampaikan pesan inti dari sebagian ayat yang disebut, serta memberikan pesan-pesan motifasi supaya siswa tetap semangat dan istiqamah dalam mengikuti pertemuan selanjutnya, (11) Penutup dan Do'a."13

Selanjutnya Penulis juga mewawancarai Ananda Ifan Febri, M. Rifky dan Suryadi mereka adalah perwakilan dari kelas 7 MTs Hidayatullah.

Ifan Febri mengatakan: "Dengan belajar metode Grand MBA belajar Bahasa Arab lebih mudah dan dapat menghafal Alquran lebih cepat". ${ }^{14}$

Pendapat M. Rifky mengatakan: "Belajar dengan metode Grand MBA bisa lebih mudah dalam memahami arti Alquran". ${ }^{15}$

Suryadi juga mengatakan: "Dengan belajar metode Grand MBA yang saya rasakan lebih teliti dalam membaca Alquran, selalu dapat kosa kata baru lebih mudah menghafal Alquran". ${ }^{16}$

Dikesempatan lain Penulis juga mewawancarai Ananda Daffa, Yusron dan M. Robby yang mereka adalah perwakilan dari kelas 8 MTs Hidayatullah.

Daffa mengatakan bahwa: "Penerapan metode Grand MBA sangat cocok diperuntukkan pelajar khususnya MTs karena tidak rumit dan bisa langsung dipraktekkan". ${ }^{17}$

Yusron juga mengatakan: "Dengan mempelajari metode Grand MBA yang

${ }^{13}$ Bahriawan, Guru Quran, Interview di kantor MTs Hidayatullah di Denpasar pada Selasa 25 Agustus 2020 pukul 13.15 WITA

${ }^{14}$ Ifan Febri, Siswa Kelas 7 MTs Hidayatullah, Wawancara Online di Denpasar pada Sabtu 1 Agustus 2020 pukul 09.10 WITA

${ }^{15}$ M. Rifky, Siswa Kelas 7 MTs Hidayatullah, Wawancara Online di Denpasar pada Sabtu 1 agustus 2020 pukul 10.00 WITA

${ }^{16}$ Suryadi, Siswa Kelas 7 MTs Hidayatullah, Wawancara Online di Denpasar pada Sabtu 1 Agustus 2020 pukul 10.15 WITA

${ }^{17}$ Dafa, Siswa Kelas 8 MTs Hidayatullah, Wawancara Online di Denpasar pada Sabtu 3 Agustus 2020 pukul 08.30 WITA saya rasakan bisa cepat lancar dalam membaca Alquran". ${ }^{18}$

M. Robby juga mengatakan: "Metode Grand MBA dapat membantu memudahkan dan memahami isi Alquran baik dalam membacanya atau pengajaran ilmu tajwidnya". ${ }^{19}$

Dikesempatan lain Penulis juga mewancarai bapak M. Hakim salah seorang masyarakat umum yang sudah pernah mengikuti metode Grand MBA, beliau mengatakan bahwa:

"Saya sangat bersyukur sekali dengan adanya program Grand MBA ini pengajarannya tidak hanya untuk anak sekolah saja tapi masyarakat umum seperti saya juga bisa mengikuti, jujur saya terbantu sekali dengan program ini karena teknik pengajarannya mudah dan praktis bahkan kita dikenalkan dari dasar-dasar ilmu tajwid, kosa kata Bahasa arab sampai kepada penafsirannya". ${ }^{20}$

Selanjutnya Penulis juga mewancarai ibu Ghofiroh salah satu masyarakat umum beliau mengatakan tentang metode Grand MBA, bahwa:

"Metode Grand MBA mungkin salah satu metode yang sangat komplit yang pernah saya ikuti disamping mudah pembelajarannya juga mendetail dalam pengajarannya kita digiring untuk benarbenar faham dalam materinya saya sudah 3 tahun mengikuti program ini dan alhamdulillah banyak ilmu yang saya dapatkan dari program ini". ${ }^{21}$

Kesimpulannya bahwa dalam penerapan metode Grand MBA disamping mudah dan praktis juga penerapannya tidak hanya diperuntukkan pelajar saja tapi untuk semua kalangan termasuk masyarakat umum bisa mengikuti Metode Grand MBA dan juga

\footnotetext{
${ }^{18}$ Yusron, Siswa Kelas 8 MTs Hidayatullah, Wawancara Online di Denpasar pada Sabtu 3 Agustus 2020 pukul 08.45WITA

${ }^{19} \mathrm{M}$. Robby, Siswa Kelas 8 MTs Hidayatullah, Wawancara Online di Denpasar pada Sabtu 3 Agustus 2020 pukul 09.45 WITA

${ }^{20} \mathrm{M}$. Hakim, Masyarakat mum, Wawancara Pribadi di Denpasar pada Jumat 28 Agustus 2020 pukul 15.23

${ }^{21}$ Ghofiroh, Masyarakat umum, Wawancara Pribadi interview di Denpasar pada Jumat 28 Agustus 2020 pukul 17.30
} 
secara umum penerapan metode Grand MBA menggunakan alat bantu atau media diantaranya adalah: Buku panduan, Alquran, papan tulis, spidol, penghapus, isyarat tangan guru, proyektor dan laptop.

\section{Peningkatan Kemampuan Membaca Alquran Siswa}

Peningkatan kemampuan membaca Alquran siswa yang Penulis maksud dalam metode Grand MBA adalah kelancaran dan ketepatan serta menterjemah Alquran dengan baik dan benar sesuai dengan kaidah-kaidah ilmu tajwid. Bapak Burhani menjelaskan pendapatnya mengenai upaya-upaya guru dalam meningkatkan kemampuan baca Alquran siswa. Isi dari pendapat Bapak Burhani dalam wawancara sebagai berikut:

"Jadi upaya guru dalam meningkatkan baca Alquran siswa yang pertama kriterianya yaitu, mengenalkan metode Grand MBA ini, kedua setiap pagi akan memulai pelajaran siswa diwajibkan membaca Alquran 1 lembar dengan tahsin sesuai ilmu tajwid yg dipandu oleh guru, ketiga mengajari siswa ilmu tajwid, yang keempat menghafal suratsurat pendek dan yang kelima melatih siswa dengan system mentoring yakni siswa yang pintar mengajari temennya yang kurang faham dalam menangkap pelajaran Alquran". 22

Jadi menurut bapak Burhani mengenai upaya guru dalam meningkatkan kemampuan baca Alquran siswa yaitu mengenalkan metode MBA, pengajaran tahsin secara klasikal, dan pengajaran ilmu tajwid.

Cara sekolah dalam memantau kemampuan baca Alquran siswa selama di lingkungan Sekolah disebutkan oleh bapak Lukman hakim, Dalam wawancara dengan beliau berisi:

"Adapun cara memantau kemampuan baca Alquran siswa di Sekolah, kita adakan evaluasi baik secara triwulan dan semester dan kita juga mengadakan ujian terbuka dan tertutup sebagai kontrol

${ }^{22}$ Burhani, Waka Kesiswaan, Wawancara Pibadi, di Denpasar pada Kamis 27 Agustus 2020 pukul 12.05 WITA terhadap kemampuan baca Alquran siswa". ${ }^{23}$

Jadi intinya memantau kemampuan baca Alquran siswa, pihak Madrasah melakukan berbagai evaluasi-evaluasi sesuai yang ada dalam silabus dan kurikulum Madrasah.

Selanjutnya mengenai penilaian kemampuan baca Alquran siswa selama di luar Sekolah, tentunya juga dilakukan cara-cara dalam menilai nya, bapak Burhani berpendapat dalam wawancara sebagai berikut:

"Di masa pandemi covid-19 ini, semua siswa diliburkan atau belajar dari rumah saja. Jadi sekolah ini tetap memberikan tugas-tugas, memberikan tugas melancarkan surat-surat yang diajarkan, menterjemahkan dan menghafalkan, dimana mereka diharuskan merekam lalu dikirimkan kepada gurunya. Absen dan buku prestasi tetap dijalankan selama proses belajar di rumah. Dengan itu sekolah tetap bisa memberikan penilaian dari tugas-tugas tersebut. Jadi penilaian tersebut tidak hanya di sekolah saja, tetapi selama di rumah juga tetap kami nilai". ${ }^{24}$

Jadi penilaian baca Alquran siswa tidak hanya di Sekolah saja, tetapi juga saat di rumah. Yaitu dengan tetap memberikan tugastugas membaca Alquran dan hafalan mereka, yang kemudian disetorkan kepada gurunya melalui foto dan rekaman suaranya. Pada kesempatan yang lain Penulis juga mewawancarai Ananda Nadya, dan Nabila mereka berdua adalah siswi MTs Hidayatullah kelas 9.

Nadya mengatakan bahwa: "Untuk meningkatkan kemampuan membaca Alquran siswa, bapak guru selalu melatih dengan memberikan tugas baca Alquran rutin setiap hari di kelas sebelum memulai pelajaran". ${ }^{25}$

Nabila juga menimpali bahwa: "Upaya guru dalam meningkatkan kemampuan

${ }^{23}$ Lukman, Kepala Madrasah, Wawancara Pribadi pada Sabtu 15 Agustus 2020 pukul 11.00 WITA

${ }^{24}$ Burhani, Waka Kesiswaan, Wawancara Pribadi di Denpasar pada Kamis 27 Agustus 2020 pukul 12.10 WITA

${ }^{25}$ Nadya, Siswa Kelas IX, Wawancara Pribadi, di Denpasar pada kamis 27 Agustus 2020 16.05 WITA 
baca Alquran siswa salah satunya memanfaatkan media pembelajaran baik itu proyektor dan audio". ${ }^{26}$

Dalam proses meningkatkan kemampuan baca Alquran siswa, tentunya terdapat solusi yang dibutuhkan dalam membantu peningkatan kemampuan baca Alquran mereka. Selanjutnya pendapat Bapak Bahriawan mengenai solusi yang dilakukan dalam meningkatkan kemampuan baca Alquran siswa yaitu sebagai berikut:

"Sama seperti yang saya ucapkan sebelumnya, solusi yang dilakukan dalam meningkatkan kemampuan baca Alquran siswa yaitu dengan mengikuti panduan langka-langkah metode Grand MBA yang ada 11 cara itu". ${ }^{27}$

Tentang siapa saja yang yang turut serta dalam upaya peningkatan kemampuan baca Alquran siswa, didapatkan jawaban dari pendapat bapak Lukman Hakim dalam wawancara sebagai berikut:

"Yang turut serta terlibat dalam peningkatan kemampuan baca Alquran siswa yaitu semua guru khususnya yg membidangi Alquran dan guru PAI serta Kepala Sekolah". ${ }^{28}$

Jadi itulah beberapa orang yang turut serta dalam meningkatkan kemampuan baca Alquran siswa di MTs Hidayatullah Denpasar.

Berdasarkan pengamatan yang dilakukan oleh penulis ketika siswa diuji dalam rangka evaluasi, kreteria yang digunakan oleh MTs Hidayatullah dalam meningkatkan kemampuan membaca Alquran siswa diantaranya adalah: (1) Kelancaran siswa dalam membaca Alquran (2) Mampu menterjemahkan Alquran sesuai buku panduan(3) Mampu menjawab pertanyaan seputar tajwid dan kosa kata Alquran (4) Mampu menghafal surat-surat pendek dari Alquran.

\section{Faktor Pendukung Dan Penghambat}

Dalam proses peningkatan kemampuan baca Alquran siswa di MTs Hidayatullah

${ }^{26}$ Nabila, Siswa Kelas IX Wawancara Pribadi, di Denpasar pada Kamis 27 Agustus 2020 16.05 WITA

${ }^{27}$ Bahriawan, Guru Quran, Wawancara Pribadi di Denpasar pada Kamis 27 Agustus 2020 13.15 WITA

${ }^{28}$ Lukman, Wawancara Pribadi pada Sabtu 15 Agustus 202011.00 WITA tentunya terdapat faktor-faktor pendukung maupun penghambatnya. Diantarnyaa karena tidak semuanya dapat berjalan dengan lancar, sehingga terdapat juga faktor-faktor penghambatnya. Penulis mewawancarai bapak Burhani terkait faktor pendukung dan penghambat dari peningkatan kemampuan baca Alquran siswa. Isi dari wawancara tersebut yaitu:

"Mengenai faktor pendukung dan penghambat dari peningkatan kemampuan baca Alquran siswa, tentunya terdapat sangat banyak. Mulai dari pendukung, faktor yang utama yaitu tenaga pendidik yang professional. Jika tenaga pendidik kurang profesional, maka penerapan metode Grand MBA kepada siswa tidak akan berjalan lancar. Karena tenaga pendidiklah yang sangat berperan dalam meningkatkan kemampuan baca Alquran siswa. Selanjutnya faktor penghambat, diantaranya yaitu kurangnya kesadaran siswa dalam mengikuti pengajaran Alquran. Faktor inilah salah satu yang dapat menghambat dari peningkatan kemampuan baca Alquran siswa". ${ }^{9}$

Jadi menurut bapak Burhani di atas mengenai faktor pendukung dalam peningkatan kemampuan baca Alquran siswa yaitu SDM tenaga pendidik yang utama.

Berdasarkan observasi dan dokumentasi Penulis melihat kualitas dewan guru yang ada di MTs Hidayatullah Denpasar sudah cukup bagus dan pofesional dalam mengajarkan Alquran dengan metode Grand MBA sebab gurunya alumni pondok pesantren sehingga pemahaman tentang Alquran sudah bagus, pemahaman tentang pembelajaran Alquran metode Grand MBA juga diperoleh dari pelatihan dan training pembinaaan pembelajaran Alquran dengan metode Grand MBA yang di lakukan oleh MTs Hidayatullah bekerjasama dengan Tim Grand MBA Pusat dan Pesantren Hidayatullah dalam setiap akhir semester atau setahun diadakan pembinaan sebanyak 2 kali untuk meningkatkan kwalitas dewan guru.

Kemudian faktor penghambatnya yaitu kurangnya kesadaran siswa dalam mengikuti

\footnotetext{
${ }^{29}$ Burhani, Wawancara Pribadi pada Sabtu 15 Agustus 2020 12.30 WITA
} 
pengajaran Alquran. Maka MTs Hidayatullah terus berusaha untuk mencari solusi dari hambatan yang ada agar pengajaran Alquran dengan metode Grand MBA bejalan dengan baik diantaranya: memberikan motivasi atau pembinaan kepada siswa yang kurang aktif secara berkala, selalu mengingatkan tentang kewajibannya sebagai siswa untuk menyadari kelalaiannya.

\section{Pembahasan}

Dari semua wawancara di atas dapat diketahui bahwa penerapan metode Grand MBA dalam meningkatkan kemampuan baca Alquran siswa sangat penting diterapkan, khususnya di MTs Hidayatullah Denpasar. Karena disana terdapat beberapa tahapantahapan maupun komitmen yang dapat meningkatkan kemampuan baca Alquran siswanya. Salah satunya yaitu program MBA (Mengajar Belajar Alquran). Kelebihan dari menerapkan metode Grand MBA ini adalah: Mudahnya para siswa memahami Alquran karena di dalamnya siswa dikenalkan mulai dari pengenalan huruf hijaiyah, makhorijul huruf, latihan membaca, mengenalkan kosa kata ayat perayat sampai menterjemahkan Alquran secara mandiri.

Dalam penerapan metode Grand MBA ini peran guru sangat penting dalam mengajarkan kepada siswanya. Seorang guru hendaknya memberikan pengajaran serta memahami kondisi para siswanya, membiasakan tepat waktu dalam mengajar dan selalu memotifasi siswanya agar lebih baik setiap waktu dan bersemangat dalam mengaji membaca Alquran. Itulah beberapa point dari penerapan metode Grand MBA ini.

Selanjutnya mengenai peningkatan kemampuan membaca Alquran siswa, pengajaran Alquran secara kontinu sangatlah berperan penting dalam meningkatkan kemampuan baca Alquran siswa hal ini nantinya sebagai bekal hidupnya dikemudian hari. Di dalam sekolah, pastinya sudah terprogram pengajaran Alquran secara kontinu harapannya agar semakin meningkatkan kemampuan baca Alquran masing-masing siswa, seperti pembiasaan baca Alquran sebelum memulai pelajaran dll. Untuk memantau peningkatan kemampuan baca Alquran para siswa selama di Sekolah, sekolah membuat buku prestasi untuk mengetahui perkembangan baca Alquran siswanya, serta dibuat evaluasi-evaluasi oleh masing-masing kelas dimana tugasnya yaitu mengevaluasi setiap program Alquran yang sudah disusun oleh pihak Sekolah.

Pembiasaan baca Alquran bukan hanya di Sekolah saja, tetapi di rumah juga diperlukan. Sosok orangtua sangat penting dalam mendampingi dan mengontrol bacaan Alquran anaknya. Jika di Sekolah anak dibiasakan untuk mengaji (akrab dengan Alquran), maka di rumah juga perlu dibiasakan seperti itu. Orangtua harus mendampingi dan mengingatkan anak-anaknya khususnya tugas yang diberikan gurunya yang berkaitan dengan Alquran. Maka dari itu hasil yang bisa didapatkan oleh siswa dalam Penerapan Metode Grand MBA adalah Pertama Kelancaran siswa dalam membaca Alquran, kedua Ketepatan siswa ketika membaca Alquran dalam melafadzkan huruf Alquran sesuai tajwid, Ketiga Kemampuan siswa membaca Alquran dengan tartil, dan yang keempat Kemampuan siswa menterjemahkan materi Alquran.

Berdasarkan pengamatan, observasi dan wawancara yang dilakukan oleh Penulis bahwa Penerapan metode Grand MBA dalam meningkatkan kemampuan membaca Alquran siswa di MTs Hidayatullah dapat dikategorikan baik, hal ini dibuktikan dengan kemampuan siswa dalam membaca dengan baik dan benar materi yang telah diberikan di Madrasah yang dipandu oleh para guru.

Mengenai faktor pendukung dan penghambat dalam peningkatan kemampuan baca Alquran siswa, banyak disebutkan oleh informan di dalam wawancara. Dalam faktor pendukung, yang terlibat di dalamnya yaitu para guru maupun semua stakeholder sekolah yang meliputi kepala sekolah, waka kesiswaan, dan lain sebagainya. Serta yang paling penting yaitu orangtua. Orangtua termasuk faktor yang sangat berpengaruh dalam peningkatan kemampuan baca Alquran siswa. Jika di sekolah adalah tugas para guru, maka pada saat di rumah yaitu menjadi tugas para orangtua. Selanjutnya faktor penghambat, yang termasuk faktor penghambat dalam peningkatan kemampuan baca Alquran siswa yaitu kurangnya kesadaran siswa Itu merupakan salah satu hal-hal yang dapat menghambat peningkatan kemampuan baca Alquran siswa. 
Maka dapat disimpulkan bahwa peranan guru di sekolah dan orangtua di rumah sangat berpengaruh dalam peningkatan kemampuan baca Alquran siswa. Guru mengajarkan Alquran secara kontinu hingga siswa terbiasa akrab dengan Alquran lalu peran orangtua di rumah melakukan pendampingan dan mengingatkan tugas dari sekolah yang berkenaan dengan Alquran harapannya dapat meningkatkan kemampuan baca Alquran anaknya.

\section{PENUTUP}

Berdasarkan pemaparan yang Penulis uraikan pada bab sebelumnya maka dapat diambil kesimpulan diantaranya adalah: Pertama, dalam prakteknya penerapan metode Grand MBA di MTs Hidayatullah Denpasar dalam meningkatkan kemampuan baca Alquran siswa menggunakan model klasikal dan model mentoring yang ada 11 teknik dalam pengajarannya, pengelompokan belajar disesuaikan dengan kelas disana terdapat beberapa tahapan-tahapan dan komitmen yang sungguh-sungguh untuk dapat meningkatkan kemampuan membaca Alquran siswanya. Dalam penerapannya peran guru sangat penting dalam mengajarkan kepada siswanya. Kedua, dalam meningkatkan kwalitas kemampuan membaca Alquran siswa mereka dikenalkan dengan metode Grand MBA ini, setiap pagi akan memulai pelajaran siswa diwajibkan membaca Alquran 1 lembar dengan tahsin sesuai ilmu tajwid yang dipandu oleh guru, mengajari siswa ilmu tajwid, dan melatih siswa dengan system mentoring yakni siswa yang pintar mengajari temennya yang kurang faham dalam menangkap pelajaran Alquran yang hasilnya dapat dirasakan siswa. Dan yang ketiga, faktor yang mendukung dalam penerapan metode Grand MBA di MTs Hidayatullah Denpasar yaitu faktor tenaga pendidik yang profesional dan orang tua. Sebab keduanya sangat berpengaruh besar dalam proses peningkatan kemampuan baca Alquran siswa. Selanjutnya faktor penghambat, antara lain faktor kurangnya kesadaran siswa. Itu merupakan salah satu hal-hal yang dapat menghambat peningkatan kemampuan baca Alquran siswa. Adapun saran yang Penulis dapat berikan adalah Pertama, Bagi Kepala Madrasah MTs Hidayatullah Denpasar, diharapkan untuk tetap memperhatikan peningkatan khususnya pelajaran bidang Alquran yang ada di MTs Hidayatullah Denpasar. Dimana bidang Alquran tersebut sangat penting bagi semua siswa sebagai bekal pegangan hidupnya kelak. Karena bekal pendidikan Alquran ibarat benteng bagi anak agar anak bisa tumbuh menjadi anak yang sholeh. Kedua, Untuk semua Guru yang membidangi Alquran diharapkan tetap kontinu memberikan pengajaran Alquran sehingga siswa dapat meningkat kemampuan baca Alqurannya. Ketiga, Untuk Penulis, selanjutnya hasil penulisan ini dapat dijadikan sebagai bahan acuan untuk penulisan selanjutnya yang berkaitan dengan metode Grand MBA pada pembelajaran Alquran dalam meningkatkan kemampuan membaca Alquran siswa.

\section{DAFTAR RUJUKAN}

Alquran dan terjemahannya. 2014. Jakarta: Departemen Agama

Abu Zakariya an-Nawawi. 2002. Riyadhu AlSholihin. Bairut Libanon: Dar Tuqun Najah

Al-Maliki Sayyid Muhammaad ibnu Maliki Alwi. 2005. Al Itqon fii ulumil Quran Bairut Libanon: Darul Fikri

Herdiansyah, Haris. 2010. Metode Penelitian Kualitatif untuk Ilmu-ilmu Sosial. Jakarta: Salemba Humanika

Muhaimin, dkk. 2002. Paradigma Pendidikan Islam. Suatu Upaya Mengefektifkan Pendidikan Agama di Sekolah. Bandung: Rosda Karya

Mulyana Dedy. 2005 Ilmu Komunikasi Suatu Pengantar. Bandung: PT. Remaja Rosdakarya

Saiful Asep Muhtadi. 2003. Metodologi Penelitian Dakwah. Bandung: CV. Pustaka Mulia

Suharsimi Arikunto. 2006. Prosedur Penelitian: Suatu Pendekatan Praktik, Edisi Revisi VI. Jakarta: PT Rineka Cipta

Trana Jaya, Agung. Grand MBA Terampil Menerjemah Alquran Dan Membaca Kitab Gundul. Jakarta: Majelis Alquran Hidayatullah (MQH)

https:/www.kanalinfo.web.id/menerapkan https://pikiran-rakyat.com/nasional/pr01290792/ironis-54\%-muslimindonesiatakbisaalquran 